Original Article

\title{
Suppressive effect of edible seaweeds on SOS response of Salmonella typhimurium induced by chemical mutagens
}

Hoida Ali Badr ${ }^{*}$, Kaori Kanemaru, Yasuo Oyama ${ }^{2}$, Kumio Yokoigawa ${ }^{2}$

${ }^{1}$ Department of Botany and Microbiology, Faculty of science, Sohag University 82524, Sohag, Egypt.

${ }^{2}$ Faculty of bioscience and bioindustry, Tokushima University, 1-1 Minamijosanjima-cho, Tokushima 770-8502, Japan

doi:

\section{Abstract}

We examined antimutagenic activity of hot water extracts of twelve edible seaweeds by analyzing the suppressive effect on the SOS response of Salmonella typhimurium induced by direct [furylframide, AF-2 and 4nitroquinoline 1-oxide, 4NQO] and indirect [3-amino-1-methyl-5H-pyrido(4,3-b) indole, Trp-P-2 and 2-amino-3-methylimidazo (4,5-f) quinoline, IQ] mutagens. Antimutagenic activities of the seaweed extracts were different from each other against each mutagen used. Among the seaweeds tested, the extract of the brown alga Eisenia bicyclis (Kjellman) Setchell was found to have the strongest antimutagenic activity irrespective of the type of the mutagen used. Total phenolic compounds in E. bicyclis extract was calculated to be $217.9 \mathrm{mg}$ GAE/g dry weight and it was very high in comparison with those of all other seaweed extracts. These experimental results indicated that the hot water-soluble extract of the brown seaweed $E$.

KEYWORDS

Seaweed,

Mutagens,

Polyscharide,

Eisenia bicyclis,

\section{CORRESPONDING}

AUTHOR

Hoida Ali Badr

hwaida.badr@science.sohag.ed u.eg bicyclis has antimutagenic potential and its high phenolic content appears to be responsible for its antimutagenic activity. The E. bicyclis extract was fractionated into polysaccharide fraction and non-polysaccharide one by ethyl alcohol precipitation and the major activity was detected in the non-polysaccharide fraction which exhibited a relatively strong antimutagenic activity against all the mutagens tested. The non-polysaccharide fraction was further separated into high- and low-molecular weight fractions and the former fraction showed much stronger activity than the latter fraction.

\section{INTRODUCTION}

In recent years there has been greater interest in investigating natural compounds with ability to protect cells from carcinogens and mutagens. Mutagens are involved in genotoxicity and carcinogenesis and are also implied in the pathogenesis of several degenerative diseases including hepatic, neurodegenerative, and cardiovascular disorders, as well as diabetes, chronic inflammation, and aging. The harmful effects of mutagens are decreased by using natural antimutagens present in plants, human diet and other sources, these include flavonoids, phenolics, coumarins, carotenoids, anthraquinones, tannins, saponins and many more (Bhattacharya 2011) these compounds could act against the initiation, promotion or progression stages of carcinogenesis (Edenharder et al. 1993) and destroy or block the DNA-damaging mutagens from outside of cells (Ruan 1989). Several researchers investigated antimutagenic activity of plant extracts (Rubem \& 
Vera 2003; Elisangela et al. 2013; Tshepiso et al. 2016; Aseesh et al. 2019); antimutagenic activities have been related with the phytochemical compounds, such as flavonoids, polysaccharides, tannins, and phenolic compounds. Phenolic compounds have been reported to be the major plant compounds with many biological properties such as anticarcinogenic, antimutagenicity, antiallergenicity and antiaging activities (Kaur et al. 2006; Yuan et al. 2009; Wang et al. 2014; Devi et al. 2015). Some investigators studied the correlation between antimutagenic activity and total phenolic content of some plant extracts and reported that antimutagenic activities of plant extracts were associated with the presence of antioxidant polyphenols in the extracts (Tshepiso et al. 2016).

Seaweeds are traditionally used for direct consumption as a good source of food and alternative medicines in Asian countries (Muhammad et al. 2000), and recently, their consumption as functional food has also spread to Western countries, they are well known as an excellent source of biologically active compounds such as soluble dietary fibers, proteins, peptides, minerals, vitamins, polyunsaturated fatty acids and antioxidants. Some researchers investigated antimutagenic activity of seaweeds (Okai et al. 1993; Okai \& Higashi-Okai 1994; Okai et al. 1994; Okai et al. 1996). They also have been known to have multiple therapeutic properties such as suppression against some types of cancer (Carper 1987). Synytsya et al. (2010) studied antitumor activity of fucoidan isolated from brown seaweed Undaria pinnatifida. Yamamoto \& Maruyama (1985) and Yamamoto et al. (1987) reported that oral intake of seaweed powder or its extract caused a decrease in the incidence rate of in vivo chemically induced carcinogenesis.

In this study we examined antimutagenic activity of hot water extracts of various edible seaweeds through the suppressive effect on the SOS response of Salmonella typhimurium induced by several chemical mutagens. $\beta$-Galactosidase activity of the bacterium with a fusion gene umuC'- 'lacZ was measured to estimate the antimutagenic activity of the extracts of seaweeds.

\section{MATERIALS AND METHODS}

S. typhimurium TA1535/pSK1002 was provided by Dr. Yoshimitsu Oda, Osaka Prefectural Institute of Public Health, Osaka. The direct mutagens used were furylframide (AF-2) and 4-nitroquinoline-1oxide (4NQO). The indirect mutagens used, which were activated by the S9 mix (cofactor A set for Ames test, Oriental Yeast Industries, Osaka), were 3-amino-1-methyl-5H-pyrido (4,3-b) indole (Trp-P2) and 2-amino-3-methylimidazo (4,5-f) quinoline (IQ). These chemical mutagens were obtained from Wako Pure Chemical Industries (Osaka).

\section{Modified umu test}

The antimutagenicity of seaweed extracts was analyzed by a slightly modified uти test (Oda $\boldsymbol{e t} \boldsymbol{a l}$. 1985), which is based on the ability of DNAdamaging agents to induce the umu operon expression and the ability of antimutagenic substances to suppress the expression. A plasmid (pSK 1002) carrying a fusion gene umuC'-'lac Z was introduced into Salmonella typhimurium TA1535. The expression and suppression of the ити operon were analyzed by measuring the $\beta$-galactosidase activity of the cells. Strain TA1535 with pSK1002 was pre-cultured at $37^{\circ} \mathrm{C}$ for $16 \mathrm{~h}$ in TGA medium ( $1 \%$ bactotrypton, $0.5 \% \mathrm{NaCl}, 0.2 \%$ glucose and $0.002 \%$ ampicillin). The culture was diluted 50 -fold with TGA medium and further incubated to an appropriate bacterial cell density (absorbance of 0.2 - 0.3 at $600 \mathrm{~nm}$ ). The standard assay mixture for analyzing the suppressive effect on the SOS response contained $20 \mu \mathrm{l}$ of each direct mutagen (final concentration: AF-2, $3 \mu \mathrm{g} / \mathrm{ml}$; 4NQO, $0.3 \mu \mathrm{g}$ $/ \mathrm{ml}$ ), a final concentration of 1 and $3 \%$ hot watersoluble extracts of seaweeds, and $2.0 \mathrm{ml}$ of the cell 
suspension described above. For the assay using indirect mutagens, $1.7 \mathrm{ml}$ of the cell suspension supplemented with $0.3 \mathrm{ml}$ of the $\mathrm{S} 9$ mix was mixed with seaweed extract and each indirect mutagen (IQ, $0.3 \mu \mathrm{g} / \mathrm{ml}$; Trp-P-2, $3 \mu \mathrm{g} / \mathrm{ml})$. The concentration of each mutagen at which the $\beta$-Galactosidase activity was induced without the inhibition of bacterial growth was selected. After incubation at $37^{\circ} \mathrm{C}$ for 2 $\mathrm{h}$, the mixture was diluted with $0.85 \% \mathrm{NaCl}$, and the cells were harvested by centrifugation at $3000 \times \mathrm{g}$ for $15 \mathrm{~min}$. The precipitate was resuspended in $0.85 \%$ $\mathrm{NaCl}$, and then the $\beta$-Galactosidase activity of the cell extract was assayed (A). The standard assay mixture without seaweed extract was used for the test as the control (B). The percentage suppression of the SOS response was calculated using the equation:

$$
(1-\mathrm{A} / \mathrm{B}) \times 100
$$

The cell extract used for measuring the $\beta$ Galactosidase activity was prepared as follows: 200 $\mu \mathrm{l}$ of the cell suspension in $0.85 \% \mathrm{NaCl}$ was vigorously mixed with $1.8 \mathrm{ml}$ of Z-buffer $(0.06 \mathrm{M}$ $\mathrm{Na}_{2} \mathrm{HPO}_{4}, 0.04 \mathrm{M} \mathrm{NaH}_{2} \mathrm{PO}_{4}, 0.01 \mathrm{M} \mathrm{KCl}, 0.001 \mathrm{M}$ $\mathrm{MgSO}_{4}$ and $0.05 \mathrm{M} \beta$-mercaptoethanol), $50 \mu \mathrm{l}$ of $0.1 \%$ sodium dodecyl sulfate and $10 \mu \mathrm{l}$ of chloroform. The enzyme reaction was initiated by adding $\quad 0.2 \mathrm{ml}$ of 2-nitrophenyl- $\beta$ - $D$ Galactopyranoside $(4 \mathrm{mg} / \mathrm{ml}$ in $0.1 \mathrm{M}$ phosphate buffer, $\mathrm{pH}$ 7.2) to the cell extract, followed by incubation at $28^{\circ} \mathrm{C}$ for $20 \mathrm{~min}$; the reaction was stopped with $1.0 \mathrm{ml}$ of $1 \mathrm{M} \quad \mathrm{Na}_{2} \mathrm{CO}_{3} . \quad \beta$ Galactosidase activity was calculated as follows:

$\beta$-Galactosidase unit $=1000(\mathrm{C}-1.75 \times \mathrm{D}) / 0.2 \times \mathrm{E}$

Here, $C$ and D represent the absorbance at 420 and $550 \mathrm{~nm}$, respectively, of the enzyme reaction mixture, and $E$ shows the absorbance at $600 \mathrm{~nm}$ of the bacterial suspension grown in the $u m u$ test.

\section{Seaweeds}

Dry edible seaweeds were purchased from a food store in Tokushima, Japan. They are twelve seaweeds, Ulva Linnaeus, 1753 (Aosa in Japanese), Ulva linza Linnaeus [Enteromorpha linza (Linnaeus) J. Agardh] (Usuba-aonori), Eisenia bicyclis (Kjellman) Setchell (Arame), Nemacystus decipiens (Suringar) Kuckuck (Mozuku), Sargassum horneri (Turner) C. Agardh (Akamoku), Chorda filum (Linnaeus) Stackhouse (Turumo), Gloiopeltis tenax (Turner) Decaisne (Funori), Mazzaella japonicua (Mikami) Hommersand (Akaba-ginnansou), Chondracanthus tenellus (Harvey) Hommersand (suginori), Undaria pinnatifida (Harvey) Suringar (Wakame), Saccharina japonica (Areschoug) Lane, Mayes, Druehl et Saunders (Kombu), and Hizikia fusiforme (Harvey) Setchell (Hijiki).

\section{Preparation of seaweed extracts}

Dry seaweeds ( 1 or $3 \mathrm{~g}$ ) milled at 20,000 rpm for 1 min with Millser-620DG were suspended in $100 \mathrm{ml}$ $\mathrm{H}_{2} \mathrm{O}$. The suspensions were autoclaved at $121^{\circ} \mathrm{C}$ for $15 \mathrm{~min}$, and centrifuged at $10,000 \mathrm{~g}$ for $15 \mathrm{~min}$. The supernatant solutions were used as $1 \%$ or $3 \%$ seaweed extracts.

\section{Determination of Total Phenolic Content}

The determination of total phenolic content of the hot water seaweed extract was performed according to the colorimetric method of Folin-Coicalteu. The seaweed extract $0.1 \%(250 \mu \mathrm{L})$ was mixed with $1.250 \mu \mathrm{L}$ of Folin-Ciocalteu reagent diluted with distilled water $(1: 10 \mathrm{v} / \mathrm{v})$. After 5 minutes, $1 \mathrm{~mL}$ of $4 \%(\mathrm{w} / \mathrm{v})$ sodium carbonate was added to the mixture. After 2 hours, the absorbance of the samples at $740 \mathrm{~nm}$ was measured with UV-VIS spectrophotometer. The total phenol content was determined by interpolating in the calibration curve constructed with standard gallic acid (the concentrations between 5 and $80 \mathrm{mg} / \mathrm{L}$ ) and expressed as $\mathrm{mg}$ gallic acid equivalents per gram of dry seaweed (mg GAE/g). 
Preparation of polysaccharide and nonpolysaccharide fractions from the seaweed extract

The polysaccharides were prepared by a slightly modified method that of Maeda and Nishizawa (1968) as follows. Ten $\mathrm{ml}$ of the extract were mixed with 4 volumes of cold ethanol and 1/10 volume of 3 $\mathrm{M} \mathrm{Nacl}$, kept for $2 \mathrm{hrs}$. at $-20^{\circ} \mathrm{C}$ and centrifuged at $6000 \mathrm{~g}$ for $15 \mathrm{~min}$. The precipitate dissolved in 10 $\mathrm{ml}$ of distilled water was used as polysaccharide fraction, and the supernatant was dried with an evaporator at $50{ }^{\circ} \mathrm{C}$ and dissolved in $10 \mathrm{ml}$ of distilled water and used as the non-polysaccharide fraction.

Separation into high- and low-molecular weight fractions of the non-polysaccaride substances.

Five $\mathrm{ml}$ of the non-polysaccharide fraction from the seaweed described above was dialyzed with a dialysis membrane (MWCO: $14 \mathrm{kDa}$ ) against $500 \mathrm{ml}$ distilled water at $4 \mathrm{oC}$ overnight. The inner fraction recovered from the dialysis bag and the outer fraction were dried by a rotary evaporation at $50{ }^{\circ} \mathrm{C}$ and dissolved in $5 \mathrm{ml}$ with distilled water.

\section{Statistical analysis}

Experiments were performed triplicate, and statistical analysis was performed by analysis of variance (ANOVA) using a software, StatView (SAS Institute, Inc., Cary, NC, USA).

\section{RESULTS}

\section{Conditions for assay of antimutagenic activity}

The concentration of seaweed extract that affect $\beta$ Galactosidase activity of Salmonella typhimurium cannot be used for the SOS response assay. Therefore, we examined the effects of different concentrations of seaweed extracts on $\beta$ Galactosidase activity. Neither inhibition nor activation against $\beta$-Galactosidase activity was observed when we used all extracts at $1 \%$ and $3 \%$ to analyze the suppressive effect on the SOS response. Therefore, these two concentrations appeared to be applicable to this modified umu test.

\section{Antimutagenic activity against direct mutagens}

As shown in Fig. (1), antimutagenic activities of the seaweed extracts were different from each other against each mutagen used. The $3 \%$ extract of a brown alga $E$. bicyclis showed a strong activity against AF-2 according to the classification proposed by Ikken et al. (1999); The antimutagenic effect was considered moderate when the inhibitory effect of extracts was in the range of $25-40 \%$ and strong when the inhibitory effect was $>40 \%$. An inhibitory effect $<25 \%$ was considered weak, and it was not recognized as a positive result. So the extracts of $C$. filum and $G$. tenax had moderate activity (Fig.1A), four extracts of $M$. japonicua, $U$. linnaeus, $H$. fusiforme and $N$. decipiens showed very weak activity at 3\% concentration, and the other investigated seaweeds did not show any activity. The extracts of E. bicyclis, C. filum, G. tenax and $H$. fusiforme seaweeds exhibited strong activities against 4NQO, the strongest one was E. bicyclis, while other extracts showed weak activities or no activity (Fig. 1B). Thus, the extract of E. bicyclis among the 12 extracts used was considered to have the highest activity against the tested direct mutagens.

\section{Antimutagenic activity against indirect mutagens}

Against an indirect mutagen IQ, most seaweed extracts showed high antimutagenic activities (Fig. $2 \mathrm{~A})$. The $3 \%$ extracts of six brown seaweeds $(H$. fusiforme, $S$. japonica, E. bicyclis, $N$. decipiens, $S$. horneri, and C. filum), the green seaweed (U. linza), and the red seaweed (G. tenax) exhibited strong antimutagenic activities. The extracts of red alga $M$. japonicua and green alga U. linnaeus showed moderate activity. Only two extracts showed no 
activity against IQ mutagen ( $U$. pinnatifida and $C$. 2, most of the extracts showed antimutagenic tenellus). Against the other indirect mutagen Trp-P- activities (Fig. 2B).

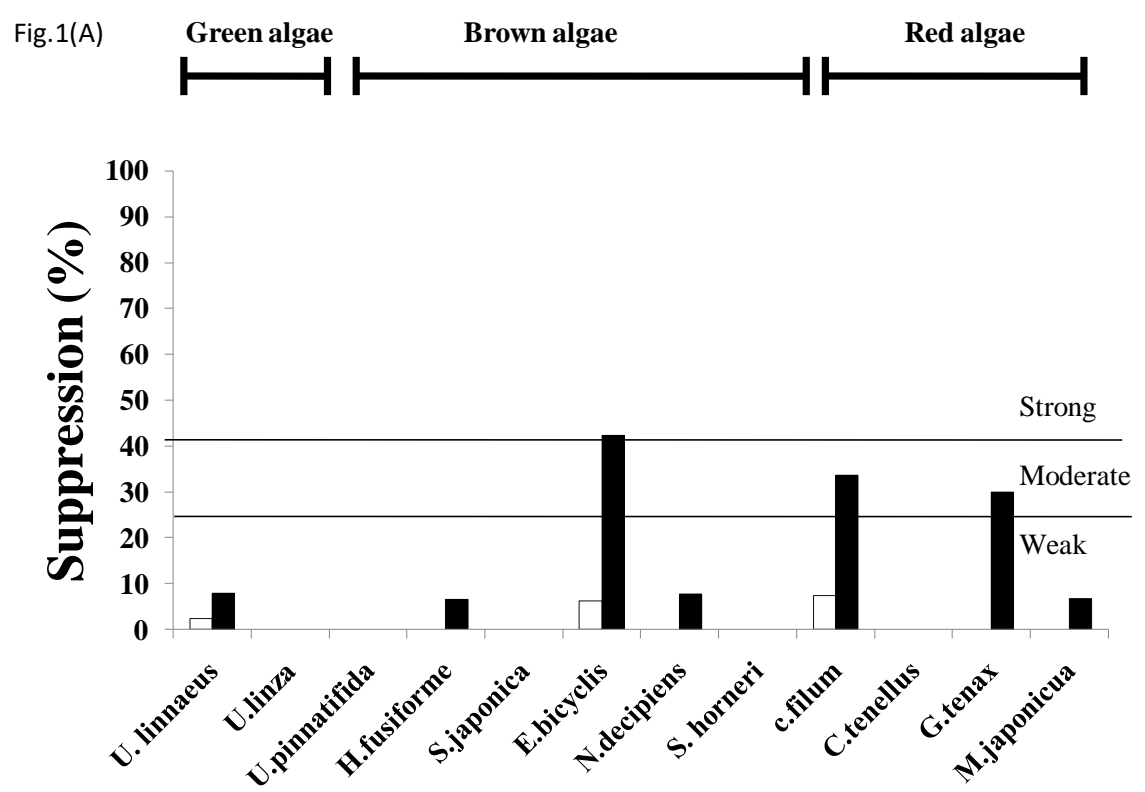

Seaweed

Figure (1A) Effects of seaweed extracts on SOS response induced by direct mutagen $(\mathrm{AF}-2,3 \mu \mathrm{g} / \mathrm{ml})$ :

Each result is expressed as the mean value of triplicate experiments, White bars: suppression at $1 \%$ seaweed extracts; and black bars: suppression at 3\% seaweed extracts. Activity reference values ( $\%$ of suppression: $>40=$ strong, $25-40=$ moderate and $<25=$ weak antimutagenic activity) were used according to Ikken $\boldsymbol{e t}$ al., (1999).

The 3\% extracts of three brown algae (E. bicyclis, $C$. filum and $N$. decipiens) and those of three red algae (M. japonicua, G. tenax and C. tenellus) showed strong activities. The extract of E. bicyclis among the extracts used was found to have the highest activity against the tested indirect mutagens.

\section{Total phenolic content}

The total amounts of phenolic compounds in the seaweed extracts were determined spectrophotometrically. The obtained results together with statistical evaluation can be seen in Table 1. The highest and simultaneously multiply exceeding phenolic content was determined in the brown seaweed Eisenia bicyclis (217.9 mg/g GAE). Quite high value was also ascertained in the red seaweed Gloiopeltis tenax (143 mg/g GAE); those extracts exhibited strong activities against most of the used mutagens. On the other hand, the extracts from the brown seaweeds Sacchasrina japonica,
Sargassum horneri and Undraia pinnatifida, the green seaweeds Ulva linza and Ulva Linnaeus, and red seaweed Chondracanthus tenellus showed absolutely the lowest values among all analyzed extracts; they showed week activities or no activities against most of the used mutagens.

Table 1. Amounts of total phenolic content (mg/g GAE) of seaweed extracts, Results are shown as mean \pm SD $(n=3)$

\begin{tabular}{|l|c|}
\hline \multicolumn{1}{|c|}{ Seaweed } & Total phenolic content \\
\hline Ulva linnaeus & $40.7 \pm 0.1$ \\
\hline Ulva linza & $31.05 \pm 2.1$ \\
\hline Undria pinnatifida & $10.9 \pm 0.1$ \\
\hline Hizikia fusiforme & $102.55 \pm 1.1$ \\
\hline Saccharina japonica & $26.7 \pm 3.4$ \\
\hline Eisenia bicyclis & $217.9 \pm 1.6$ \\
\hline Nemacystus decipiens & $58.2 \pm 0.2$ \\
\hline Sargassum horneri & $24.4 \pm 1.1$ \\
\hline Chorda filum & $124.45 \pm 1.2$ \\
\hline Chondracanthus tenellus & $20.8 \pm 0.4$ \\
\hline Gloiopeltis tenax & $143 \pm 1.1$ \\
\hline Mazella japonicua & $67.5 \pm 1.8$ \\
\hline
\end{tabular}



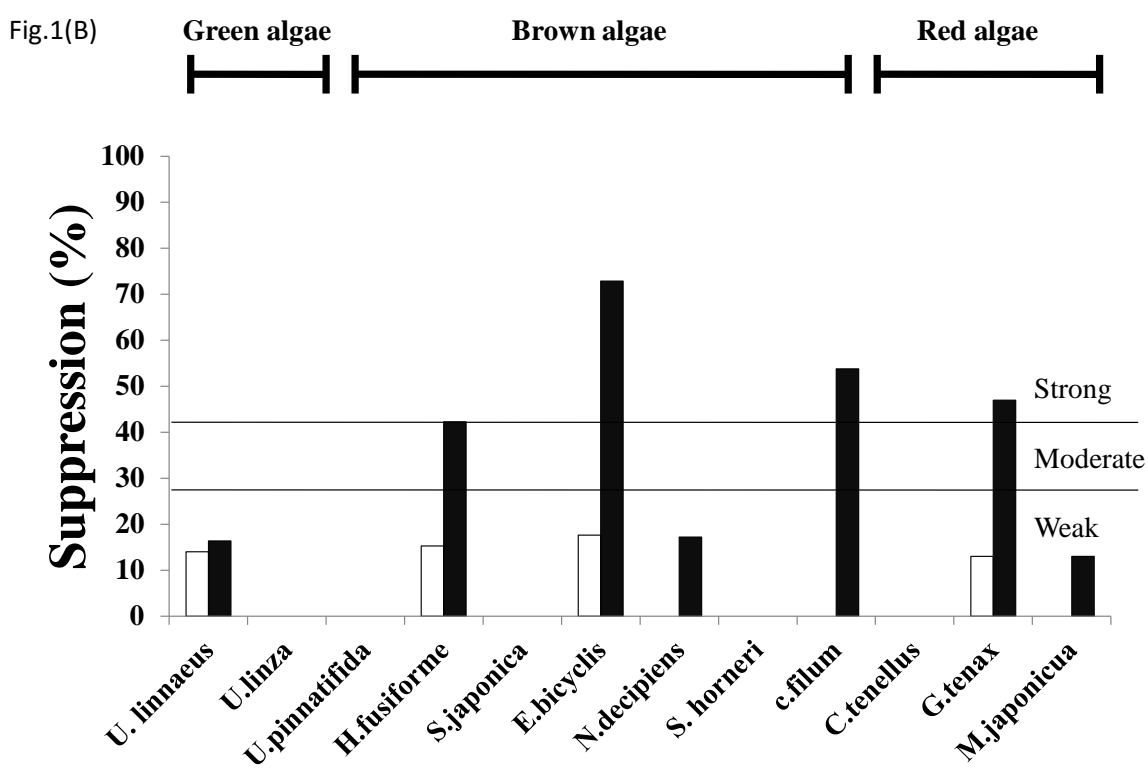

Seaweed

Figure (1B) Effects of seaweed extracts on SOS response induced by direct mutagen (4NQO $0.3 \square \mathrm{g} / \mathrm{ml}$ ):

Each result is expressed as the mean value of triplicate experiments, White bars: suppression at $1 \%$ seaweed extracts; and black bars: suppression at $3 \%$ seaweed extracts. Activity reference values ( $\%$ of suppression: $>40=$ strong, $25-40=$ moderate and $<25=$ weak antimutagenic activity) were used according to Ikken $\boldsymbol{e t}$ al., (1999).

To analyze the biochemical properties of the antimutagenic activity derived from E. bicyclis extract we fractionated it into polysaccharide and non-polysaccharide fractions and analysed the effects of both fractions on $и т и C$ gene expression induced by direct (AF-2, 4NQO) and indirect (IQ, Trp-p- 2) mutagens. The results obtained indicated that the major activity was detected in Nonpolysaccharide fraction against all the tested mutagens and the lower activity in polysaccharide one as shown in (fig 3). Furthermore, to analyse the biochemical properties of the non- polysaccharide fraction, we fractionated it into high- and lowmolecular weight fractions by an equilibrated dialysis method with the Float-A-Lyzer G2 (MWCO: $14 \mathrm{kDa}$ ), then we assayed antinutagenic activities of both fractions. As shown in fig. 4, the high molecular weight fraction showed a higher activity against all mutagens tested. This result suggests that the major portion of the antimutagenic non- polysaccharides from E. bicyclis has a molecular weight more than $14 \mathrm{kDa}$. These results indicated that the hot water extract from E. bicyclis contain antimutagenic substances (polysaccharides and non-polysaccharides) and their biochemical properties are different from each other.

\section{DISCUSSION}

We examined antimutagenic activity of hot water extracts of twelve edible seaweeds by analyzing the suppressive effect on the SOS response of $S$. typhimurium induced by direct and indirect mutagens. The results indicated that some of the investigated extracts of the twelve edible seaweeds had a potent protective activity against mutagenesis induced by direct mutagens and indirect mutagens.

As a whole, our results indicated that most seaweed extracts exhibited strong activity against indirect mutagens (Trp-P-2 or IQ) but a relatively weak activity against direct mutagens (AF-2 or 4NQO), these results were in accordance with Okai et al., 1993; they studied antimutagenic activity of the extracts from some edible seaweeds against mutagenesis using direct mutagens (MNNG \& AF2) and indirect mutagens (2-AAF \& Trp-P-1), they 
reported that the used seaweed extracts contain heterogenous antimutagenic activities against genotoxic substances and that the extracts showed strong activities against indirect mutagens (2-AAF, Trp-P-1), but weak inhibitory effects on direct mutagens (MNNG, AF-2).
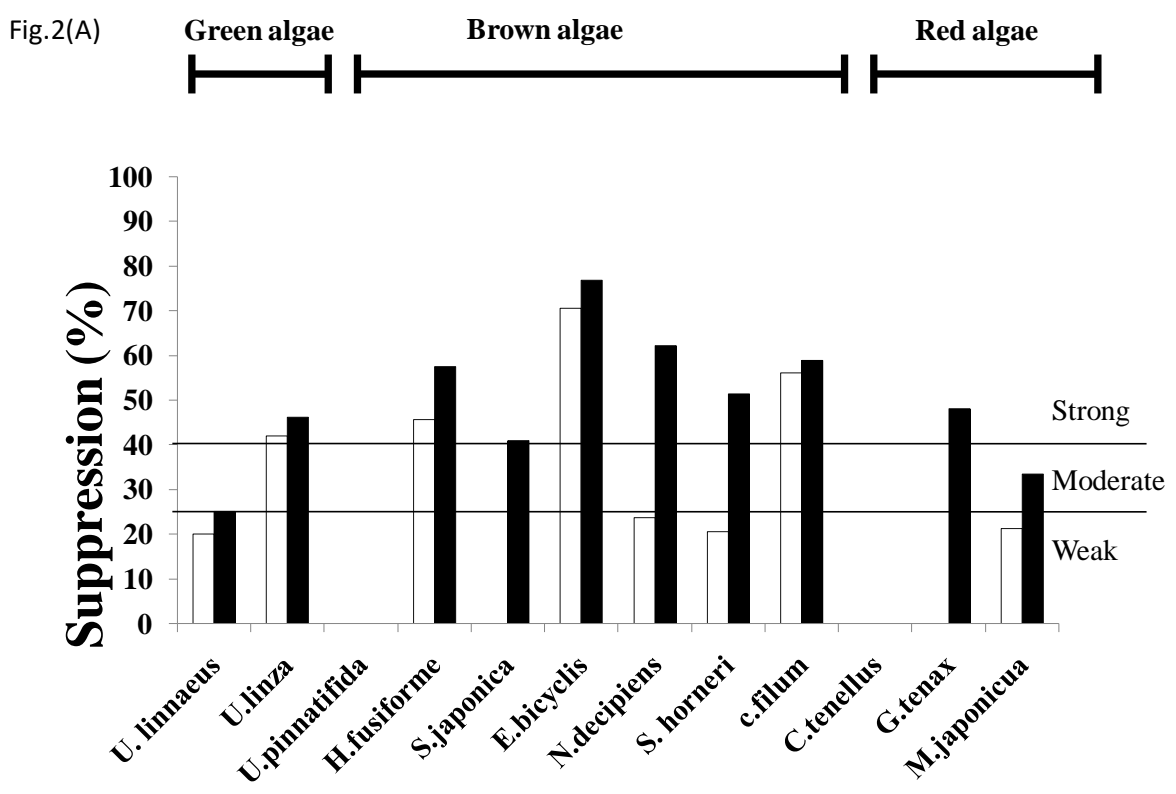

Seaweed

Figure (2A) Effects of seaweed extracts on SOS response induced by indirect mutagen (IQ, $0.3 \square \mathrm{g} / \mathrm{ml}$ )

Each result is expressed as the mean value of triplicate experiments. White bars: suppression at $1 \%$ seaweed extract; and black bars: suppression at $3 \%$ seaweed extracts. Activity reference values ( $\%$ of suppression: $>40=$ strong, $25-40=$ moderate and $<25=$ weak antimutagenic activity) were used according to Ikken et al., (1999).
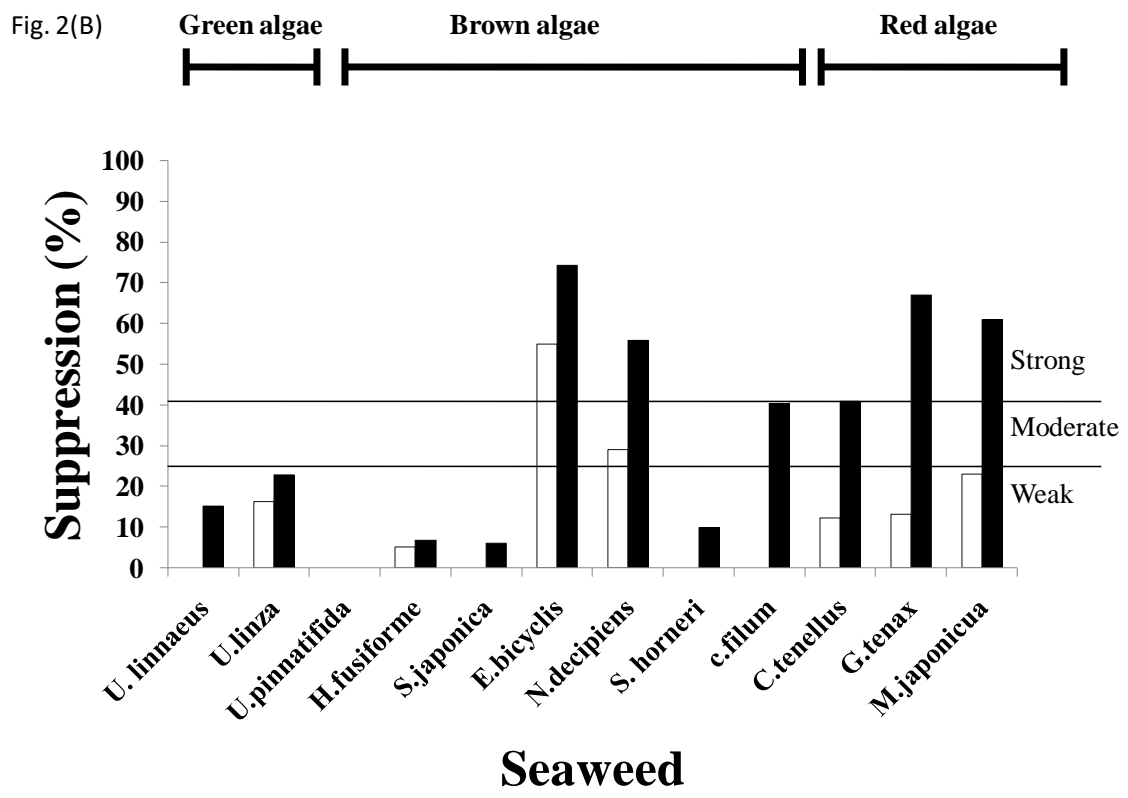

Figure (2B) Effects of seaweed extracts on SOS response induced by indirect mutagen (Trp-P-2, $3 \square \mathrm{g} / \mathrm{ml}$ )

Each result is expressed as the mean value of triplicate experiments. White bars: suppression at $1 \%$ seaweed extract; and black bars: suppression at $3 \%$ seaweed extracts. Activity reference values ( $\%$ of suppression: $>40=$ strong, $25-40=$ moderate and $<25=$ weak antimutagenic activity) were used according to Ikken $\boldsymbol{e t}$ al., (1999). 
The results in this study indicated that 3\% concentration of seaweed extracts showed higher antimutagenic activities than $1 \%$ concentrations, this was in agreement with finding of Osuna-Ruiz et al. (2016), they studied antimutagenic activity of acetone extracts of $C$. sertularioides, $R$. ripariumand $S$. filamentosa at different concentrations on $S$. typhimurium TA98 and TA100 tester strains, and found that inhibition of aflatoxin B1 (AFB1) mutagenicity on both tester strains decreased with decrease of the extract concentration.
Phenolic compounds found in algae include the phlorotannins found in brown algae and in lower amounts in some red algae. They are integral structural components of cell walls, and they have been studied due to their therapeutic properties (anticancer, antioxidative, antibacterial, anti-allergic, anti-diabetes, anti-aging, anti-inflammatory and antiHIV activities) (Li et al. 2011; Thomas \& Kim 2011), phenolic compounds have a major role in the chemoprevention of cancer due to their antimutagenic/anticarcinogenic activities (Kaur et al. 2006).

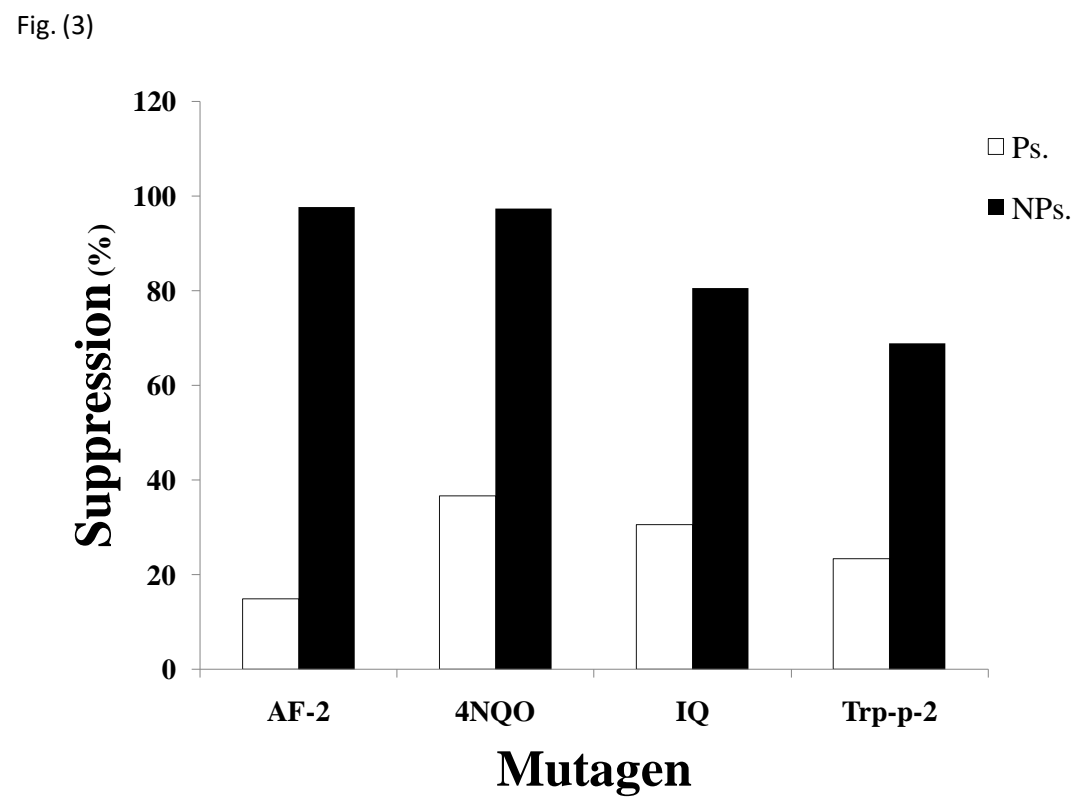

Figure (3) Effects of polysaccharides and non-polysaccharide fractions of E. bicyclis on SOS response induced by direct. Each result is expressed as the mean value of triplicate experiments. White bars: suppression by polysaccharide fraction; and black bars: suppression by non-polysaccharide fraction.

Our results indicated that total phenolic compounds in Eisenia bicycles extract was (217.9 $\mathrm{mg} / \mathrm{g}$ GAE). Quite high value was also determined in the red seaweed Gloiopeltis tenax $(143 \mathrm{mg} / \mathrm{g}$ GAE); those extracts exhibited strong activities against most mutagens used. On the other hand, the extracts from the brown seaweeds Saccharina japonica, Undaria pinnatifida, Chondracanthus tenellus and the green seaweeds Ulva linza and Ulva Linnaeus showed absolutely the lowest values among all analyzed extracts; those seaweeds showed week activities or no activities against most of the used mutagens. This result was in accordance with Ludmila et al. (2015) they investigated total phenolic content of brown (Laminaria japonica, Eisenia bicyclis, Hizikia fusiformis, Undaria pinnatifida) and red (Porphyra tenera, Palmaria palmata) seaweeds and reported that Eisenia bicyclis was the sample with the highest phenolic content. Our results indicated that the extract from the brown seaweed E. bicyclis exhibited relatively strong activities against all the investigated mutagens.

Although further study required to know the exact compounds which are responsible for the activity of 
the other seaweed extracts against the indirect mutagens (Trp-P-2 \& IQ), there was a clear correlation between phenolic content of most seaweed extracts and their antimutagenic activity in case of using the direct mutagens (AF-2 \& 4NQO), so we believed that high phenolic content in Eisenia bicycles extract responsible for its activity against the mutagens, this was in accordance with

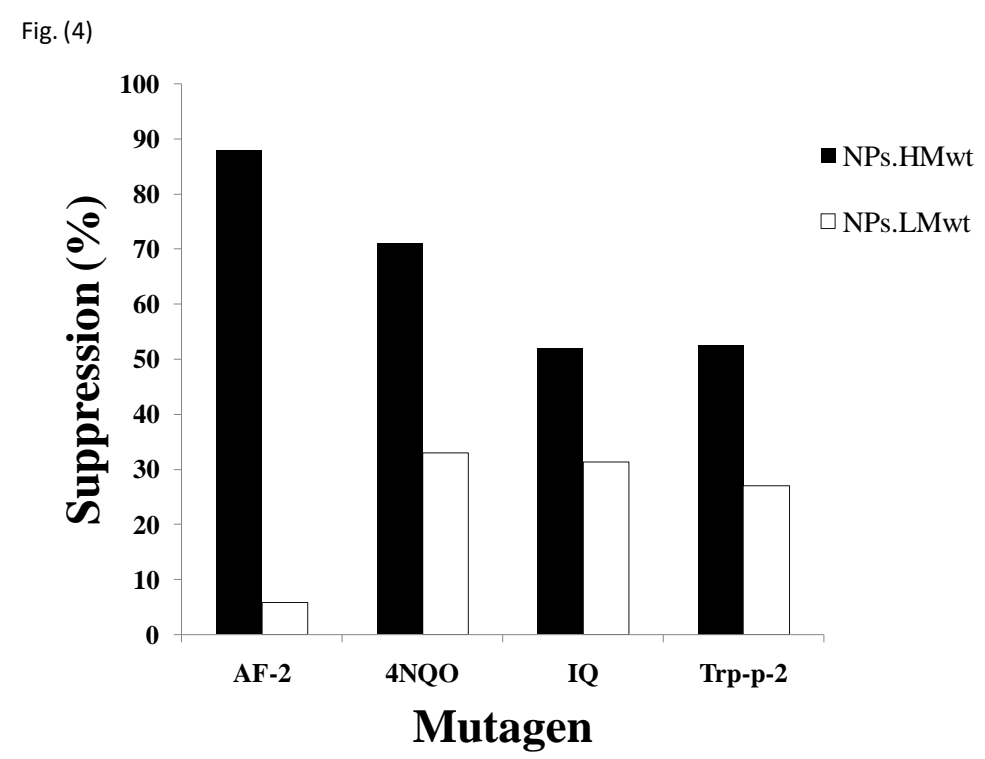

Figure (4) Effects of high- and low molecular weight fractions of E.bicyclis non-polysaccharide on SOS response induced by direct. Each result is expressed as the mean value of triplicate experiments. White bars: suppression by low molecular weight fraction; and black bars: suppression by hight molecular weight fraction.

We analyzed the biochemical properties of the antimutagenic activity derived from E. bicyclis so divided it into polysaccharide and nonpolysaccharide substances as mentioned in the results and the later fraction showed stronger antimutagenic activities against all the mutagens used, these results were in accordance with Okai $\boldsymbol{e t}$ al. (1993); they reported that the major activity was detected in the non-polysaccharide fraction of Laminaria japonica extract and minor activity was found in the polysaccharide fraction. Okai \& Higashi-Okai (1994) also found a significant antimutagenic activity in the hot water extract of the brown alga, Hijikia fusiforme. However, they reported that the major activity was detected in the polysaccharide fraction, and that the minor activity
(Phadungkit $\boldsymbol{e t}$ al. 2012) they evaluated antioxidant and antimutagenic activities of five Thai edible plant extracts, and also Devi et al. (2015), they evaluate the antioxidant and antimutagenic activity of $C$. caesia Roxb. Rhizome extracts; all of them reported that the high antimutagenic activity has been presented to phenolic compounds. was found in the non-polysaccharide fraction of the extracts.

Next we separated the antimutagenic activities of the non-polysaccharide fraction into high- and lowmolecular weight fractions by a dialysis membrane (MWCO: $14 \mathrm{kDa}$ ) and assayed for antinutagenic activities in both fractions, and the high molecular weight fraction showed higher activity against all the tested mutagens, this result suggests that the major portion of the antimutagenic non- polysaccharides from E. bicyclis has a molecular weight more than $14 \mathrm{kDa}$. Antimutagenic activity of methanol-soluble extracts of eight varieties of edible seaweeds against Trp-P-1 mutagen was also studied by Okai $\boldsymbol{e t}$ al . (1994), their results indicated that Enteromorpha prolifera and Porphyra tenera showed strongest suppressive activities compared with the other 
investigated seaweeds, and that these seaweeds contained considerable amounts of $\beta$-carotene. Okai et al. (1996) analyzed active components with antimutagenic activity in methanol extract of the red seaweed Porphyra tenera, they found that the antimutagenic activity of the seaweed extract was strongly associated with the functions of $\beta$-carotene, chlorophyll a and lutein.

\section{REFERENCE}

Aseesh P., Tarun B., Sushma T., Bhatt I. D. and Rawal R. S. (2019). Phenolic compounds, antioxidant capacity and antimutagenic activity in different growth stages of in vitro raised plants of Origanum vulgare L. Molecular biology reports, 46: 2231-2241.

Bhattacharya S. (2011). Natural antimutagens: A review. Research Journal of Medicinal Plant, 5(2): 116-126.

Carper J. (1987). Seaweed or Kelp.In: The Food Pharmacy, pp. 264-268. B antam Books, New York.

Devi H. P., Mazumder P. B. and Devi L. P. (2015). Antioxidant and antimutagenic activity of Cutcuma caesia Roxb. Rhizome extracts. Toxicology Reports, 2: 423-428.

Edenharder R., van Petersdorf I. and Rauscher V. (1993). Antimutagenic effects of flavonoids, chalcones and structurally related compounds on the activity of 2-amino-3-methylimidazol (4,5-f) quinoline (IQ) and other heterocyclic amine mutagens from cooked food. Mutat. Res, 287: 261-274.

Elisangela D., Igor Vivian A., Ana C. C.; Thiago J. B., Lilian T. D. T. and Veronica E. P. V. (2013). Antimutagenic Effect of Medicinal Plants Achillea millefolium and Bauhinia forficate In Vivo. Evidence-Based Complementary and Alternative Medicine.

Ikken Y., Morales P., Martı'nez A., Marı'n M. L., Haza A. I. and Cambero M. I. (1999). Antimutagenic effect of fruit and vegetable ethanolic extracts against $\mathrm{N}$-nitrosamines evaluated by the Ames test. Journal of Agriculture and Food Chemistry, 47: 32573264.

Kaur K., Arora S., Singh R., Walia H., Nagapal A. and Kumar S. (2006). Antimutagenic / anticarcinogenic potential of plant polyphenols. A review. In Verschaeve, L. Appl Microbiol Biotechnol. Kerala: Research Signpost, pp.23-59.

Li Y. X., Wijesekara I., Li Y. and Kim S. K. (2011). Phlorotannins as bioactive agents from brown algae. Process Biochemistry, 46: 22192224 .

Ludmila M., Ladislava M., Jarmila V., Jana O., Jiri M., Jiri S. and Tunde J. (2015). Phenolic Content and Antioxidant Capacity in Algal Food Products. Molecules, 20: 1118-1133.

Maeda M. and Nishizawa K. (1968). Fine structure of laminaran of Eisenia bicycilis, Journal of Biochemistry, 63: 199-206.

Muhammad S. A., Muhammad J., Muhammad S., Muhammad K. P., Shaista H. and Vigar U. A. (2000). Metabolites of marine algae collected from Karachi-coasts of Arabian Sea. Natural Product Sciences, 6(2):61-65.

Oda Y., Nakamura S., Oki I., Kato T. and Shinagawa H. (1985). Evaluation of the new system (umu-test) for the detection of environmental mutagens and carcinogens. Mutation Research, 147: 219-229.

Okai Y. and Higashi-Okai K. (1994). Identification of antimutagenic activities in the extract of an edible brown alga, Hijikia fusiforme (Hijiki) by umu gene expression system in Salmonella typhimurium (TA 1535/pSK 1002). Journal of Science Food and Agriculture, 66: 103-109.

Okai Y., Higashi-Okai K., Yano Y. and Otani S. (1996). Identification of antimutagenic substances in an extract of edible red alga, Porphyra tenera (Asadusa-nori). Cancer Lett, 100: 235-240.

Okai Y., Higashi-Oki K. and Nakamura S. (1993). Identification of heterogenous antimutagenic 
activities in the extract of edible brown seaweeds, Laminaria japonica (Makonbu) and Undaria pinnatifida (Wakame) by the umu gene expression system in Salmonella typhimurium (TA1535/pSK1002). Mutation Research, 303: 63-70.

Okai Y., Higashi-Oki K., Nakamura S., Yano Y., and Otani S. (1994). Suppressive effects of the extracts of Japanese edible seaweeds on mutagen-induced ити $\mathrm{C}$ gene expression in Salmonella typhimurium (TA 1535/pSK 1002) and tumor promotor-dependent ornithine decarboxylase induction in $\mathrm{BALB} / \mathrm{c} \quad 3 \mathrm{~T} 3$ fibroblast cells. Cancer Lett, 87: 25-32.

Osuna-Ruiz I., López-Saiz C., Burgos-Hernández A., Velázquez C., Nieves-Soto M., and Hurtado-Oliva M. (2016): Antioxidant, antimutagenic and antiproliferative activities in selected seaweed species from Sinaloa, Mexico. Pharm Biology, 54: 2196-2210.

Phadungkit M., Somdee T. and Kangsadalampai, K. (2012). Phytochemical screening, antioxidant and antimutagenic activities of selected Thai edible plant extracts. Journal of Medicinal Plants Research, 6(5): 662-666.

Ruan C. (1989). Antimutagenic effect of foods and chemoprevention of cancer. Acta Guangxi Medical Collages, 1: 68-71.

Rubem C. H. and Vera M. F. V. (2003). Antimutagenic activity of extracts of natural substances in the Salmonella/microsome assay. Mutagenesis, 18(2): 113-118.

Synytsya A., Kim W. J., Kim S. M., Pohl R., Synytsya A., Kvasnička F., Čopíková J. and Park Y. I. (2010). Structure and antitumor activity of fucoidan isolated from sporophyll of Korean brown seaweed Undaria pinnatifida. Carbohydrate Polymers, 81: 4148.

Thomas N. V., Kim S. K. (2011). Potential pharmacological applications of polyphenolic derivates from marine brown algae. Environ. Toxicological Pharmacology 32: 325-335.
Tshepiso J. M, Esameldin E. E., Lyndy. J. M., Luc V., and Jacobus N. E. (2016). The correlation between antimutagenic activity and total phenolic content of extracts of 31 plant species with high antioxidant activity. BMC Complementary and Alternative Medicine., 16: 490 .

Wang Z., Zhou F., and Quan Y. (2014). Antioxidation and immunological activity in vitro of polysaccharides from Phellinus nigricans mycelia. International Journal of Biological Macromolecules, 64: 139-143.

Yamamoto I., and Maruyama H. (1985). Effect of dietary seaweed preparations on 1,2dimethylhydrazine-induced intestinal carcinogenesis in rats. Cancer Lett, 26: 241251.

Yamamoto I., and Maruyama H., Moriguchi M. (1987). The effect of dietary seaweeds on 7,12-dimethylbenz[a]anthracene-induced mammary tumorigenesis in rats. Cancer Lett, 35: $109-118$.

Yuan C., Huang X., Cheng L., Bu Y, Liu G., Yi F., Yang z. and Song F. (2009). Evaluation of antioxidant and immune activity of Phellinus ribis glucan in mice. Food Chemistry, 115: 581-584. 